were removed, $90-93$ per cent of the hydrochloric acid and 97-98 per cent of the grit and dust from the pulverised fuel boiler. The exit gas from the plant is so free from sulphur dioxide that it is practically odourless, although the sense of smell can detect a very minute trace of this gas.

\section{River Flow Records}

The paper on "Flow of the River Dee" (Aberdeenshire), by Capt. W. N. MeClean, read before the British Association meeting at Aberdeen last September, has been issued in pamphlet form, reprinted from Engineering, with a memorandum which indicates the progress made in the survey of the river subsequent to the original date of the paper, and an addendum illustrating the manner in which the records are to be set out in tabular form for publication. The Dee has a catchment area of 790 sq. miles to Aberdeen, and for the purposes of the survey it was divided into four subsidiary areas, with flow-gauging stations at Balmoral, Dennet, Cairnton and Cults. The author states that he has found that the summer flow in certain Scottish rivers of about 100 to 700 sq. miles catchment, may be taken, roughly, as from $1 / 5$ to $1 \mathrm{cu}$. $\mathrm{ft}$. per sec. per sq. mile, according to area. Flood flows are much more complicated. The author further notes the difficulty of measuring low flows with current meters, as they are at present not very reliable for velocities of less than $1 \mathrm{ft}$. per sec. He suggests the difficulty may be overcome in the future by a temporary contraction of the channel, so as to increase the velocity. Two types of apparatus are in use on the Dee: namely, one in which the meter is suspended from a wire and another in which a rod is the means of support. It is known that, in turbulent flows, the wire-suspended meter tends to set to the current and to give excessively high values. The combined use of the two methods enables a serviceable comparison to be made of their respective accuracies. "The records obtained should prove of great public utility and the co-operation of two authorities directly interested, the City of Aberdeen and the Fishery Board of the Dee, has been secured in establishing the gauging stations. Capt. MeClean points out that if there were a recognised association for these river records, the water interests would become subscribing members of the association, receiving the completed records in return for the standard tables of water levels prepared by them. selves.

\section{Thunderstorms in Great Britain}

THE third annual report of the survey of thunder. storms in the British Isles, entitled "Summer Thunderstorms", has been received (Huddersfield : Thunderstorm Census Organisation. 2s. 6d.). Much of it has been written by Mr. S. Morris Bower, the honorary director of the Survey, but articles have been contributed by Sir C. V. Boys on "Progressive Lightning" and by S. T. E. Dark on "Trees Struck by Lightning". The Survey is an amateur enterprise somewhat similar to what the British Rainfall
Organization was in its early stages. Its development is doubtless made more difficult because the economic importance of the distribution of thunderstorms is, at present, less than that of rainfall. There is the further difficulty that the study of thunderstorms cannot be effectively prosecuted apart from the general study of synoptic meteorology, except in limited directions. In the purely statistical problem of obtaining the best possible cartographical representation of the occurrence of thunder, the Survey had the advantage in 1933 of a number of voluntary observers-1,291-nearly four times greater than the number of full climatological stations co-operating with the Meteorological Office, an advantage greater than the numbers alone suggest in that the observers at official stations do not concentrate on one phenomenon. This report deals with some of the statistical results obtained in 1933, and also includes maps showing the number of days on which storms occurred in different parts of the British Isles in each of the months April-September 1932. The frequencies shown give the number of civil days during which one or more thunderstorms pass overhead, and are therefore not comparable with figures based on the international definition of a day of thunderstorm at any place as one on which thunder is heard at that place. The article on "Trees Struck by Lightning" is accompanied by some interesting photographs showing spiral scoring of tree trunks; it can be seen that the lightning may descend the tree either in a left or a right hand spiral. Sir C. V. Boys's article deals with photographic studies of the duration and length of individual flashes, their direction and velocity, and suggests means for initiating a flash by firing a rocket into the thunder cloud, to assist in studies of this kind.

\section{The Imperial Forestry Institute, Oxford}

In the tenth annual report of the Imperial Forestry Institute for the year 1933-34 (Oxford : The Holywell Press Ltd., 1934) it is stated that the number of students was still considerably below normal, owing to the stoppage of the recruitment for the forest services of the Colonial Office, though it compared favourably with the number of the previous year. Apart from regular students, a number of forest officers, at home on leave, and others attended the Institute for short periods to work in the libraries and the laboratories. The Institute is still shorthanded so far as the staff is concerned. During the year, a decree was passed by the University allocating a site within the Parks area for the erection of a new building for the Department of Forestry, including the Imperial Forestry Institute. Some progress has been made in regard to preliminary plans and estimates for the building; but it has not yet been possible to commence building operations owing to lack of sufficient financial provision; this matter, it is said, is receiving further attention. The income of the Institute is made up of grants from the Crown Agents, Dominions and others, Forestry Commission, and the Department of Scientific and Industrial Research. An interesting part of the report is given 
to a record of the progress which is being made with the collection and identification of the species of the forest floras of the various Colonies and Protectorates. Details are given under the Colonies grouped under West Tropical Africa, East Tropical Africa, South Central Tropical Africa, the South Temperate Region and a few other territories. The report gives full details of the various branches of work upon which the Institute is engaged, including brief accounts of the tours abroad undertaken by the students and others attending the courses.

\section{Plant Breeding in the U.S.S.R.}

The Bureaux of Plant Genetics at Cambridge and Aberystwyth have published jointly a bulletin of 58 pages (price $3 s .6 d$.) on plant breeding in the Soviet Union. This is mainly a translation from the Russian of an address given by Prof. W. I. Vavilov at a conference on the planning of plant breeding and genetics investigations, held at Leningrad in 1932, and is followed by a detailed programme of work on different economic plants. The congress effected a reorganisation of the various genetical institutions in Russia and the adoption of a new system of fourteen plant breeding centres. This bulletin will be of service to all who are engaged in plant breeding, particularly on the practical side. It sets forth in outline the immense collections of economic plant material which have been made by expeditions to many parts of the world, notably Afghanistan, Kashmir, Abyssinia, Mexico, Bolivia and Peru. These embrace more than 200 crops, including 29,200 living specimens of wheat, 13,000 of barley, more than 9,000 of maize, 1,000 of potatoes, etc. There has resulted the conception of geographical centres for the production of varieties of many crops. The work includes cereals, vegetables, fruit trees, medicinal and fibre plants, etc. A series of new potato species with diverse characters and multiple chromosome numbers was found in the Andes. The vast amount of breeding work in progress and projected during the second five-year plan (1933-37) is outlined in the latter part of the bulletin.

\section{Grassland Research}

The Imperial Economic Committee has issued its report (No. 27) on grassland seeds (London : H.M. Stationery Office. 1s. net). As grass may be regarded as the vital raw material of most of the produce of livestock, and farming and grassland products accounted for more than 20 per cent of the value of all imports into the United Kingdom in 1932, the importance of good grassland management cannot be overemphasised. The discovery that local strains are, for their own locality, often superior to commercial strains as regards persistence and leafiness has opened the way for considerable improvements, but even greater advances are being made by the production of pedigree strains at the plant breeding stations. If, however, economic benefit is to be gained from all this experimental work, far-reaching changes in organisation of the seed industry will be needed. The primary task is that of ensuring an adequate supply of stock seed of the pedigree strains and of maintaining them true to type when they pass in commercial quantities through the ordinary channels of trade, and to achieve this end the breeding stations will need to be supplemented by seed farms. In this connexion, the report gives particulars of schemes for seed certification and other methods which have been adopted in various countries, notably in Sweden, Canada and New Zealand, and the success with which such schemes have met suggests that districts such as Northern Ireland, where considerable quantities of rye-grass seed are produced annually, might benefit from a similar type of organisation if combined with the experiments now in progress with improved stock seed.

\section{Farm Pumps}

AN illustrated booklet entitled "Pumps for Farm Water Supply" by C. A. Cameron Brown of the Institute for Research in Agricultural Engineering, Oxford, has just been published (Oxford Univ. Press, price $1 s .6 d$.). Its appearance is opportune although plans for its preparation were made before the drought in 1933 and 1934 had rendered the question of rural water supplies such an urgent matter. The inquiry has been carried out particularly with the view of helping the farmer and isolated small country house dweller to obtain an adequate water supply from whatever source may be available at as low a cost as possible. Small electrically driven pumps capable of delivering upwards of 250 gallons per hour are available at prices from $£ 10$ to $£ 12$. No pump should be installed without an assurance from the makers that it will give the performance required to meet the particular set of conditions in each particular case, but with this proviso they should prove entirely reliable. The gravity tank is still the commonest, and probably the simplest, method of providing service, but the pressure-tank system has an advantage where the installation of a gravity tank presents constructional difficulty or is likely to be unsightly, but it is at a disadvantage in districts where electricity supply failures are frequent. The actual running cost of these small pumps is low in comparison with the cost of public water supply in towns. Test figures under working conditions show from $0 \cdot 66$ electrical units to $1 \cdot 89$ units per 1,000 gallons.

\section{Zoological Society of London}

AT the monthly general meeting of the Zoological Society of London it was stated that the total number of visitors to the Society's Gardens during the year 1934 was $1,639,611$, the receipts amounting to $£ 50,969$, an increase of $£ 3,432$ as compared with the previous year. The total number of visitors to the aquarium during 1934 was 265,604 ; the receipts amounted to $£ 9,063$, which represents an increase of $£ 242$ as compared with 1933. The total number of visitors to Whipsnade Park during 1934 was 516,411 ; the receipts were $£ 22,223$, an increase of $\mathfrak{1 3 , 4 6 3}$ as compared with the previous year. 